\title{
Karsykdom ved inflammatorisk leddsykdom
}

Bruk av ikke-steroide antiinflammatoriske legemidler kan beskytte mot hjerte- og karsykdom hos pasienter med ankyloserende spondylitt, ifølge en ny studie.

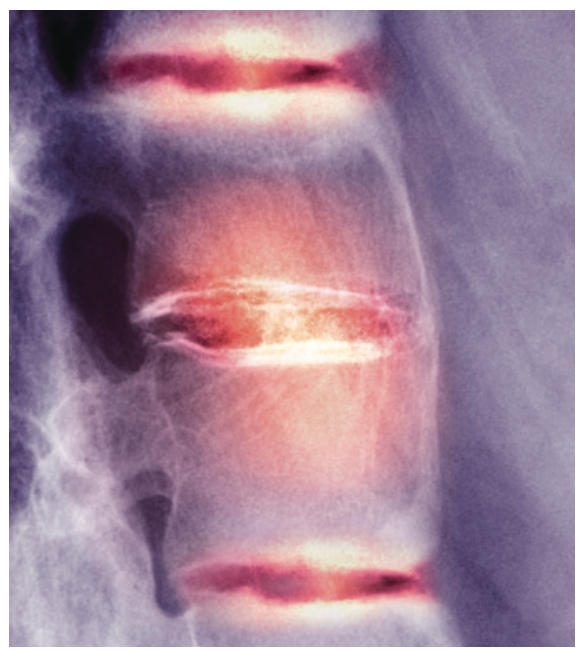

Illustrasjonsfoto: Science Photo Library
Pasienter med ankyloserende spondylitt har økt kardiovaskulær risiko. I en kanadisk kohortstudie med over 100000 deltakere ble det bekreftet at slike pasienter har økt kardiovaskulær dødelighet (hasardratio 1,36; $95 \%$ KI 1,13-1,65) (1). Studien viste også at alder (høy), kjønn (mann), lav sosioøkonomisk status og manglende bruk av ikke-steroide antiinflammatoriske midler ga ytterligere økt risiko.

- Dette er en stor studie, av høy kvalitet, og forhåpentligvis vil den føre til økt bevissthet rundt den økte risikoen for hjerte- og karsykdom hos pasienter med ankyloserende spondylitt, sier Ivana Hollan, som er lege og seniorforsker ved Revmatismesykehuset i Lillehammer. - Det har vært lite oppmerksomhet omkring tidlig diagnostikk og forebygging av hjerte- og karsykdom hos slike pasienter sammenliknet med for eksempel diabetespasienter, sier hun.

- Studien indikerer dessuten at ikke-steroide antiinflammatoriske midler beskytter mot hjerte- og karsykdom ved spondyloartritt. Dette kan virke som et paradoks, siden disse midlene ellers er kjent for å gi økt risiko for hjerte- og karsykdom. Studier ved revma- toid artritt har vist liknende funn, så én mulig forklaring kan være at inflammasjon spiller en større rolle ved hjertesykdom hos pasienter med inflammatorisk leddsykdom enn i befolkningen ellers, og at det nettopp er den antiinflammatoriske effekten som bidrar til å beskytte mot hjerte- og karsykdom, fortsetter hun.

- Et annet viktig funn i studien er assosiasjonen mellom lav sosioøkonomisk status og risiko for død av vaskulære årsaker. Lav sosioøkonomisk status er en prediktor for en rekke negative helseeffekter. Dette viser at tverrfaglig samarbeid med sosionom, ergoterapeut, fysioterapeut og andre yrkesgrupper med sikte på å fremme pasientens muligheter til å delta $\mathrm{i}$ arbeidslivet, er viktig, sier Hollan.

\section{Martine Rostadmo}

Tidsskriftet

\section{Litteratur}

1. Haroon NN, Paterson JM, Li P et al. Patients with ankylosing spondylitis have increased cardiovascular and cerebrovascular mortality: a populationbased study. Ann Intern Med 2015; 163: 409-16.

\section{Atrieflimmer og dødelighet hos kritisk syke}

\section{Atrieflimmer er en uavhengig risikofaktor for $\mathrm{d} ø \mathrm{~d}$ hos intensivpasienter har en ny studie fra USA vist.}

Det er vist i tidligere studier at atrieflimmer er assosiert med økt dødelighet hos kritisk syke pasienter, spesielt ved sepsis. I en prospektiv kohortstudie som nylig er publisert $\mathrm{i}$ tidsskriftet Critical Care Medicine, har man undersøkt om denne arytmien er en uavhengig risikofaktor for død og om det har betydning for utfallet hvorvidt tilstanden er nyoppstått eller kjent fra tidligere (1).

Over 1700 kritisk syke voksne pasienter som hadde vært innlagt i medisinsk eller generell kirurgisk intensivavdeling i minst to dager, ble inkludert. 236 av disse (13\%) hadde atrieflimmer, hos 123 oppstått for første gang og hos 113 som residiv. I begge tilfeller var atrieflimmer assosiert med kjønn (mann), etnisitet (kaukasisk), alder (høy), hjertesykdom, organsvikt og økt dødelighet under opphold i sykehus, spesielt hos dem uten sepsis. Behandling av atrieflimmer hadde ingen effekt på dødeligheten. Nyoppstått atrieflimmer var i tillegg assosiert med økt diastolisk dysfunksjon, økt vasopressorbruk og kumulativt større positiv væskebalanse.
- Denne studien bekrefter at nyoppstått eller residiverende atrieflimmer hos pasienter $\mathrm{i}$ en intensivavdeling indikerer dårlig prognose, sier Kristina Haugaa, som er overlege og førsteamanuensis ved Kardiologisk avdeling, Oslo universitetssykehus, Rikshospitalet. - Selv om forfatterne fremstiller atrieflimmer som en uavhengig risikofaktor for død, må vi nok fortsatt oppfatte flimmer hos eldre intensivpasienter som en generell markør på alvorlig sykdom og høy komorbiditet og derfor dårlig prognose. Kausalitet mellom atrieflimmer og død er ikke vist $\mathrm{i}$ denne studien, sier Haugaa.

\section{Liv-Ellen Vangsnes}

Tidsskriftet

\footnotetext{
Litteratur

1. Shaver CM, Chen W, Janz DR et al. Atrial Fibrillation is an independent predictor of mortality in critically ill patients. Crit Care Med 2015; 43: 2104-11.
}

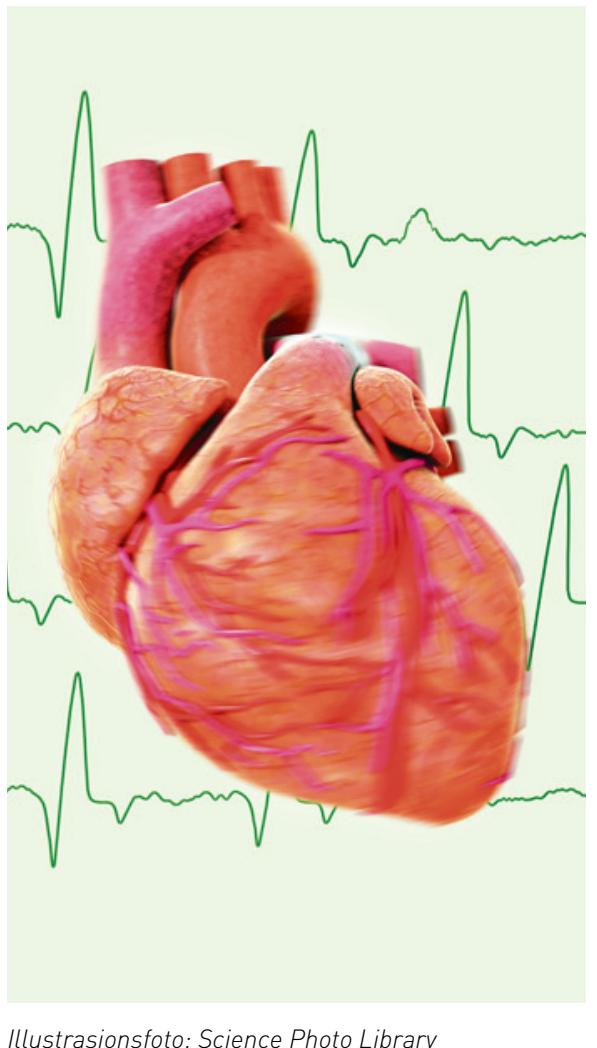

